\title{
Physiological significance of $\mathrm{P} 2 \mathrm{X}$ receptor-mediated vasoconstriction in five different types of arteries in rats
}

\author{
Lu Li • Zhen-Hua Jia $\cdot$ Chao Chen $\cdot$ Cong Wei • \\ Jian-Ke Han • Yi-Ling Wu $\cdot$ Lei-Ming Ren
}

Received: 29 October 2010 / Accepted: 1 March 2011 /Published online: 11 May 2011

(C) Springer Science+Business Media B.V. 2011

\begin{abstract}
P}_{2} \mathrm{X}_{1}$ receptors, the major subtype of $\mathrm{P} 2 \mathrm{X}$ receptors in the vascular smooth muscle, are essential for $\alpha, \beta$-methylene adenosine 5 '-triphosphate $(\alpha, \beta$-MeATP)induced vasoconstriction. However, relative physiological significance of $\mathrm{P} 2 \mathrm{X}_{1}$ receptor-regulated vasoconstriction in the different types of arteries in the rat is not clear as compared with $\alpha_{1}$-adrenoceptor-regulated vasoconstriction. In the present study, we found that vasoconstrictive responses to noncumulative administration of $\alpha, \beta$-MeATP in the rat isolated mesenteric arteries were significantly smaller than those to single concentration administration of $\alpha, \beta$-MeATP. Therefore, we firstly reported the characteristic of $\alpha, \beta$-MeATP-regulated vasoconstrictions in rat tail, internal carotid, pulmonary, mesenteric arteries, and aorta using single concentration administration of $\alpha, \beta$-MeATP. The rank order of maximal vasoconstrictions for $\alpha, \beta$ $\operatorname{MeATP}\left(E_{\max \cdot \alpha, \beta \text {-MeATP }}\right)$ was the same as that of maximal vasoconstrictions for noradrenaline $\left(E_{\max \cdot \mathrm{NA}}\right)$ in the internal carotid, pulmonary, mesenteric arteries, and aorta. Moreover, the value of $\left(E_{\max \cdot \alpha, \beta-\mathrm{MeATP}} / E_{\max \cdot \mathrm{KCl}}\right) /\left(E_{\max \times \mathrm{NA}} / E_{\max \cdot \mathrm{KCl}}\right)$ was 0.4 in each of the four arteries, but it was 0.8 in the tail artery. In conclusion, $\mathrm{P} 2 \mathrm{X}_{1}$ receptor-mediated vasoconstrictions are equally important in rat internal carotid,
\end{abstract}

L. Li $\cdot$ C. Chen $\cdot$ L.-M. Ren $(\bowtie)$

Department of Pharmacology,

Institute of Chinese Integrative Medicine,

Hebei Medical University,

361 East Zhong-shan Road,

Shijiazhuang 050017, Hebei, People's Republic of China

e-mail: ren-leiming@263.net

\section{Z.-H. Jia $\cdot$ C. Wei · J.-K. Han • Y.-L. Wu}

The Integration of Traditional and Western Medical Research Academy of Hebei Province,

238 Tianshan Street,

Shijiazhuang 050035, Hebei, People's Republic of China pulmonary, mesenteric arteries, and aorta, but much greater in the tail artery, suggesting its special role in physiological function.

Keywords $\alpha, \beta$-Methylene ATP - Noradrenaline $\cdot \mathrm{P}_{2} \mathrm{X}_{1}$ receptor $\cdot \alpha_{1}$-Adrenoceptor - Isolated artery .

Vasoconstriction $\cdot$ Rat

\section{Introduction}

The sympathetic purinergic co-transmission involving noradrenaline (NA) and adenosine $5^{\prime}$-triphosphate (ATP) is present in a variety of blood vessels. Both purinergic (prazosin-resistant) component and adrenergic (prazosinsensitive) component were shown to involve the neurogenic vasoconstriction induced by electrical field stimulation in different types of blood vessels including the rabbit ear [1], saphenous [2], hepatic [3], and splenic artery [4]. However, the ratio of NA:ATP released by the sympathetic nerves supplying different blood vessels is variable. The purinergic component is relatively minor $(\sim 10 \%)$ in rat tail artery [5], whereas nerve-mediated responses are largely purinergic in rabbit splenic artery [4]. In rabbit mesenteric artery ATP is the sole excitatory transmitter, although NA is released and contributes to feedback inhibition [6].

P2 receptors are widely distributed in the cardiovascular system and are important in the regulation of vascular tone [7]. The $\mathrm{P} 2 \mathrm{X}_{1}$ receptor is the principal $\mathrm{P} 2 \mathrm{X}$ receptor subtype expressed on most vascular smooth muscles $[8$, 9] and responsible for the purine nucleotide-induced arterial contraction $[10,11] . \alpha, \beta$-MeATP, a stable analogue of ATP, evoked transient constrictions of the femoral, tail, uterine, and large mesenteric arteries taken from the wild-type mice, but these responses were abolished in the arteries taken 
from $\mathrm{P}_{2} \mathrm{X}_{1}$ receptor-deficient mice [11]. Thus, $\alpha, \beta$-MeATP has been considered as a useful agent to investigate $\mathrm{P} 2 \mathrm{X}_{1}$ receptor-mediated vasoconstriction [12]. However, an appropriate administration regime of $\alpha, \beta$-MeATP in vitro using isolated arteries has not been yet evaluated carefully, because the agent causes profound desensitization of $\mathrm{P} 2 \mathrm{X}_{1}$ receptors. Previous studies showed the noncumulative concentration-response curve for $\alpha, \beta$-MeATP when $\alpha$, $\beta$ MeATP was repetitively applied to the rat mesenteric artery and thoracic aorta at the time interval of $10-20 \min [10$, 13]. However, some investigators used a single concentration of $\alpha, \beta$-MeATP (each arterial segment was only exposed to $\alpha, \beta$-MeATP once) in the rat mesenteric artery and thoracic aorta to obtain the concentration-response curve $[14,15]$. Moreover, $\alpha, \beta$-MeATP was even added to the organ bath in a cumulative manner to obtain a concentration-response curve in the rat thoracic aorta and pulmonary artery $[16,17]$.

In pilot experiments using isolated rat mesenteric artery, we noted that vasoconstrictive response to a single concentration of $\alpha, \beta$-MeATP was much bigger than that during noncumulative administration of $\alpha, \beta$-MeATP, indicating a possible pharmacological artifact reported in the published studies where cumulative or noncumulative administration of $\alpha, \beta$-MeATP was applied. In this study, we compared the vasoconstrictive response to a single concentration of $\alpha, \beta$-MeATP with that to noncumulative administration of $\alpha, \beta$-MeATP in rat mesenteric artery rings. In addition, we investigated the differences in $\alpha, \beta$-MeATPinduced vasoconstrictions in rat-isolated thoracic aorta, pulmonary, internal carotid, mesenteric, and caudal arteries, and we compared the differences between $\mathrm{P}_{2} \mathrm{X}_{1}$ receptorinduced and $\alpha_{1}$-adrenoceptor-induced vasoconstrictive responses in above rat arteries.

\section{Materials and methods}

Animals

Male Wistar rats (300-350 g) were provided by the Laboratory Animal Center of Hebei Medical University (China). Rats were given the standard laboratory chow and

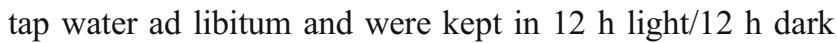
cycle in the animal care facility. All animals used in the present study received humane care in compliance with institutional animal care guidelines. All procedures were approved by the Local Institutional Committee.

\section{Chemicals}

[-]-Noradrenaline (NA) bitartrate, $\alpha, \beta$-MeATP (lithium salt), desmethylimipramine hydrochloride, deoxycorticos- terone acetate, yohimbine hydrochloride, propranolol hydrochloride, and acetylcholine hydrochloride were obtained from Sigma Chemical. Deoxycorticosterone acetate was dissolved in 1,2-propanediol. The final concentration of 1,2-propanediol in the tissue bath did not affect the vascular responses to NA. Other agents were dissolved in distilled water.

\section{Arterial preparations}

Rats were anesthetized by hypodermic injection of urethane $(1.5 \mathrm{~g} / \mathrm{kg})$, then killed by cutting femoral artery, resulting in exsanguination. After chest and abdomen were opened by a midline incision, thoracic aorta, right pulmonary arteries, and superior mesenteric artery were carefully removed. An anterior midline incision was made on the neck, and the carotid arteries were exposed. The left and right internal carotid artery was isolated and exposed from its origin at the common carotid artery bifurcation to its entry point into the skull. The caudal artery was surgically exposed from the ventral side, then dissected free from surrounding tissues and removed. Isolated arteries were maintained in ice-cold Krebs-Henseleit $(\mathrm{K}-\mathrm{H})$ solution containing (mmol/l) [4]: $\mathrm{NaCl} 133, \mathrm{KCl} 4.7, \mathrm{NaH}_{2} \mathrm{PO}_{4} 1.35, \mathrm{NaHCO}_{3}$ 16.3, $\mathrm{MgSO}_{4}$ 0.61, glucose 7.8, and $\mathrm{CaCl}_{2}$ 2.52. The vascular endothelium was removed by gently rubbing the lumen with a scored polythene cannula (outside diameter $0.2-2.5 \mathrm{~mm}$ ), the external diameter of which was slightly smaller than the internal diameter of the blood vessel [18]. Ring segment (4 mm long) without endothelium was mounted horizontally in a $10 \mathrm{ml}$ organ bath by carefully inserting tungsten wire through the lumen of the arterial ring preparation and anchoring it to a stationary support. Another tungsten wire similarly inserted was connected to an isometric tension transducer coupled to a polygraph (ERT-884, Youlin Electron, Kaifeng, China) [19, 20] to record a change in tension of the preparation. Preloads were applied to the preparations of aorta (2.0 g) [21], pulmonary artery $(1.0 \mathrm{~g})$ [22], internal carotid artery $(1.0 \mathrm{~g})$, mesenteric artery $(1.0 \mathrm{~g})$ [23], and tail artery $(0.75 \mathrm{~g})$ [24]. The preparations were allowed to equilibrate for $1 \mathrm{~h}$ in $\mathrm{K}-\mathrm{H}$ solution. The solution was maintained at $37^{\circ} \mathrm{C}$ and aerated with $95 \% \mathrm{O}_{2}$ and $5 \% \mathrm{CO}_{2}$ (pH 7.4). A successful removal of the arterial endothelium was confirmed by the loss of relaxation response to acetylcholine (ACh, $1 \mu \mathrm{mol} / \mathrm{l})$ in precontracted arterial rings with NA [25].

\section{Experimental protocols}

In each of the arterial preparations, the following three procedures were performed. A cumulative concentrationresponse curve for NA $(0.0001-100 \mu \mathrm{mol} / \mathrm{l})$ was firstly constructed to test the vasoconstrictor responsiveness of the 
preparation. Then a further equilibration for $1 \mathrm{~h}$ was needed. At the end of the isolated arterial experiments, a cumulative concentration-response curve for $\mathrm{KCl}(10-$ $120 \mathrm{mmol} / \mathrm{l}$ ) was constructed, and the wet weight of each preparation was measured.

\section{Vasoconstrictive responses to $\alpha, \beta$-MeATP administered in different manners in the mesenteric artery}

To avoid the rapid desensitization of $\mathrm{P} 2 \mathrm{X}_{1}$ receptors by $\alpha, \beta$-MeATP [26], we tested the two administration regimes in the following experiments as previously described $[4$, 27]. In five mesenteric arterial preparations, $\alpha, \beta$-MeATP $(0.1,1.0,10$, and $100 \mu \mathrm{mol} / 1)$ was added noncumulatively to the organ bath at $1 \mathrm{~h}$ intervals, and a concentrationresponse curve for $\alpha, \beta$-MeATP was generated per preparation $[4,27]$. When the vasoconstrictive response to the last dose reached the maximum, the preparation was thoroughly washed. In other 20 mesenteric arterial preparations, a single concentration of $\alpha, \beta$-MeATP at $0.1,1.0,10$, or $100 \mu \mathrm{mol} / 1$ was added to the organ bath, respectively (each arterial preparation was only exposed to $\alpha, \beta$-MeATP once), and the resultant responses of several preparations exposed to different concentrations were grouped together to form a concentration-response curve $[14,15]$. When each vasoconstrictive response to $\alpha, \beta$-MeATP reached its maximal height, the preparation was thoroughly washed.

\section{Vasoconstrictive responses to NA in the thoracic aorta and pulmonary, internal carotid, mesenteric, and caudal arteries}

In all arterial preparations, desmethylimipramine $(0.1 \mu \mathrm{mol} /$ 1), deoxycorticosterone $(5 \mu \mathrm{mol} / 1)$, yohimbine $(0.3 \mu \mathrm{mol} / 1)$, and propranolol $(1 \mu \mathrm{mol} / \mathrm{l})$ were added to the bath solution for $30 \mathrm{~min}$ to block neuronal and extra neuronal uptake of NA, and $\alpha_{2}$ and $\beta$-adrenoceptors, respectively [28]. Then, a second cumulative concentration-response curve for NA $(0.0001-100 \mu \mathrm{mol} / \mathrm{l})$ was constructed in each arterial preparation of the pulmonary, internal carotid, mesenteric, and caudal arteries, and aorta to observe $\alpha_{1}$-adrenoceptorinduced vasoconstriction.

Vasoconstrictive responses to single concentration of $\alpha, \beta$-MeATP in the thoracic aorta and pulmonary, internal carotid, and caudal arteries

In each arterial preparation of the four different arteries, a single concentration of $\alpha, \beta$-MeATP at $0.1,1.0,10$, or $100 \mu \mathrm{mol} / \mathrm{l}$ was added to the organ bath (each arterial preparation was only exposed to $\alpha, \beta$-MeATP once), and the responses of several preparations exposed to different concentrations were grouped together to form a concentration-response curve.

\section{Statistics}

Vasoconstrictive responses to NA and $\alpha, \beta$-MeATP were expressed as the maximal change in tension $(\mathrm{g})$, as a value normalized to tissue wet weight $(\mathrm{g} / \mathrm{mg}$ tissue), or as a percentage of the maximal vasoconstriction to $\mathrm{KCl}(\%$ $\mathrm{KCl})$. Values presented here are the mean \pm S.E. mean. Two-way analysis of variance was used to compare any differences between two sets of concentration-dependent response curves. If $F$ statistic was significant, we further compared the individual datum with its respective control value using Bonferroni's test. The $\log \mathrm{EC}_{50}$ values of NA and $\alpha, \beta$-MeATP producing concentration-dependent vasoconstrictions were analyzed and calculated by nonlinear regression (curve fit) of Prism 5.00. In order to estimate $\mathrm{EC}_{50}$ values of $\mathrm{KCl}$, we drew a line graph with $\mathrm{mmol} / \mathrm{l}$ of $\mathrm{KCl}$ as $X$-axis and percent (responses) as $Y$-axis in each of the preparations and estimated a value of $\mathrm{EC}_{50}$ on the $X$ axis (intercept on $X$-axis) for the concentration-response curve of $\mathrm{KCl}$ in each preparation. We compared the maximal vasoconstriction to $\mathrm{KCl}$, the tissue wet weight of arterial preparations and $\log \mathrm{EC}_{50}$ between two groups using unpaired $t$ test. $P$ values $<0.05$ were considered statistically significant. The data were analyzed using GraphPad Prism version 5.00 (San Diego, CA, USA).

\section{Results}

Vasoconstrictive responses to $\alpha, \beta$-MeATP administered in different manners in the mesenteric artery

Before exposing the mesenteric artery to $\alpha, \beta$-MeATP, the concentration-response curve for NA in preparations used in the group where single concentration of $\alpha, \beta$-MeATP (single concentration administration group, SCAG) was subsequently applied was not significantly different from that in the group of noncumulative administration of $\alpha, \beta$ MeATP (noncumulative administration group, NCAG) $(P>0.05$, Fig. 1). In addition, no significant differences in wet weight of the mesenteric arterial ring segments were observed in the two groups (SCAG, $0.8 \pm 0.02 \mathrm{mg}, n=20$; NCAG, $0.8 \pm 0.1 \mathrm{mg}, n=5 ; P>0.05)$. However, the concentration-response curve for $\alpha, \beta$-MeATP in the preparations exposed to a single concentration of the agent was significantly different from that exposed to a noncumulative administration of the agent $(P<0.05$, Fig. 2$)$. When the vasoconstrictive responses were normalized to tissue wet weight, vasoconstrictive responses to $100 \mu \mathrm{mol} / \mathrm{l} \alpha, \beta$ - 


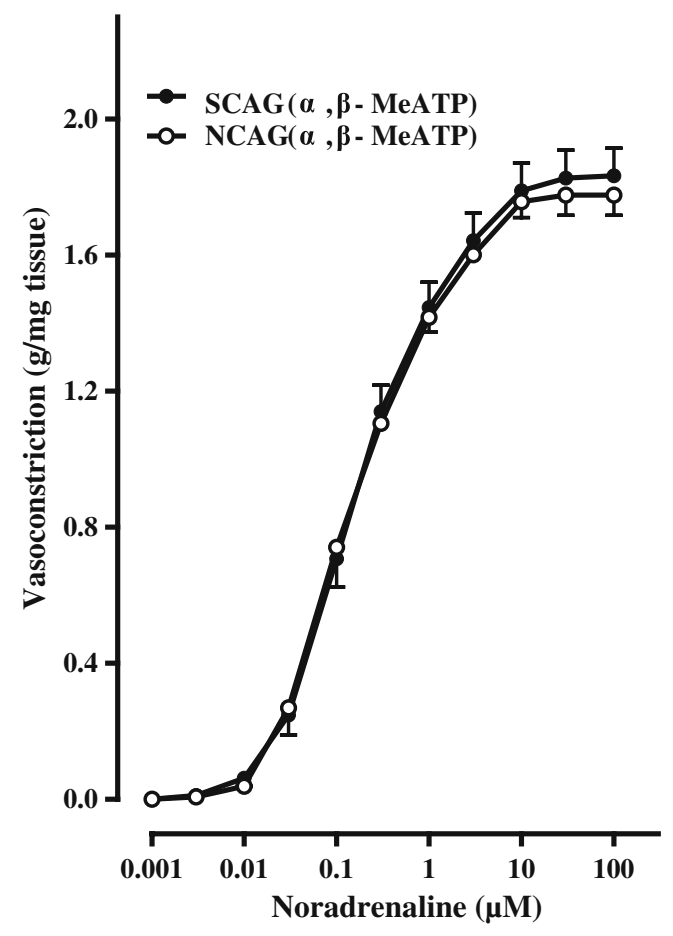

Fig. 1 Vasoconstrictive responses of the mesenteric arteries to noradrenaline in single concentration administration $[\alpha, \beta$-methylene ATP $(\alpha, \beta$-MeATP $)$ group [SCAG $(\alpha, \beta$-MeATP $), n=20]$ and in noncumulative administration $(\alpha, \beta$-MeATP) group [NCAG $(\alpha, \beta$ MeATP), $n=5$ ]. Points represent the mean values, and vertical bars show S.E. mean
MeATP administered in single concentration manner and noncumulative manner were $0.7 \pm 0.04 \mathrm{~g} / \mathrm{mg}$ tissue and 0.4 $\pm 0.1 \mathrm{~g} / \mathrm{mg}$ tissue, respectively $(P<0.05$, Fig. 2a). However, when the vasoconstrictive responses were normalized to the maximal contraction of $120 \mathrm{mmol} / 1 \mathrm{KCl}, \alpha, \beta$-MeATP $(100 \mu \mathrm{mol} / \mathrm{l})$-induced vasoconstrictive responses were not significantly different between SCAG $(48.6 \pm 5.2 \%)$ and NCAG $\left(38.0 \pm 2.5 \%\right.$; $P>0.05$, Fig. 2b). The $-\log \mathrm{EC}_{50}(\mathrm{~mol} / \mathrm{l})$ value of $\alpha, \beta$-MeATP in SCAG $(5.5 \pm 0.2 ; n=20)$ was not significantly different from $5.2 \pm 0.2$ in NCAG $(n=5 ; P>0.05)$.

At the end of the experiments, the vasoconstrictive responses to $\mathrm{KCl}$ in preparations used in the group of single concentration of $\alpha, \beta$-MeATP were significantly greater than that of noncumulative administration of $\alpha, \beta$-MeATP $(P<0.05$ and $P<0.01$, Fig. 3$)$. The $\mathrm{EC}_{50}(\mathrm{mmol} / \mathrm{l})$ value of $\mathrm{KCl}$ in NCAG was $38.1 \pm 3.1(n=5)$, significantly greater than $30.1 \pm 0.8$ in SCAG $(n=20, P<0.01)$. Moreover, both the $\mathrm{EC}_{50}$ values of $\mathrm{KCl}$ were significantly greater than $\mathrm{EC}_{50}$ value of $\mathrm{KCl}$ in the preparations exposed to a second cumulative administration of NA $(P<0.01$, Table 1$)$.

Vasoconstrictive responses to NA in the thoracic aorta and pulmonary, internal carotid, mesenteric, and caudal arteries

The second cumulative concentration-response curves for NA $(0.0001-100 \mu \mathrm{mol} / \mathrm{l})$ were constructed in each arterial preparation of the thoracic aorta and pulmonary, internal carotid, mesenteric, and caudal arteries. NA produced
Fig. 2 Vasoconstrictive responses to $\alpha, \beta$-methylene ATP expressed as $\mathrm{g} / \mathrm{mg}$ tissue (a) or as percentage of the maximal vasoconstriction to $120 \mathrm{mmol} / 1 \mathrm{KCl}(\mathbf{b})$ in the mesenteric arteries used in the groups of single concentration administration $(n=20)$ and noncumulative administration $(n=5)$. Points represent the mean values, and vertical bars show S.E. mean. $* P<0.05$ and $* * P<0.01$ vs. single concentration a

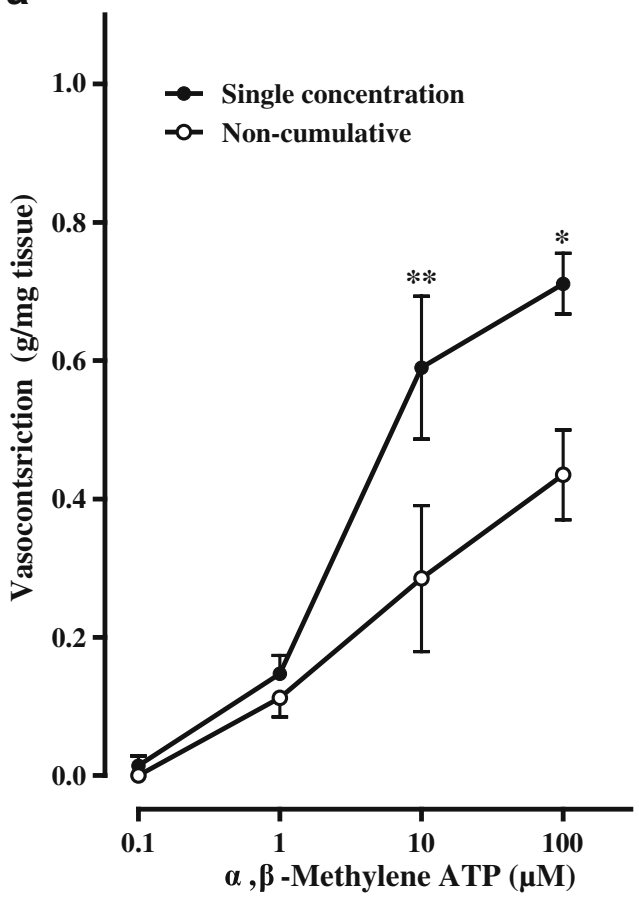

b

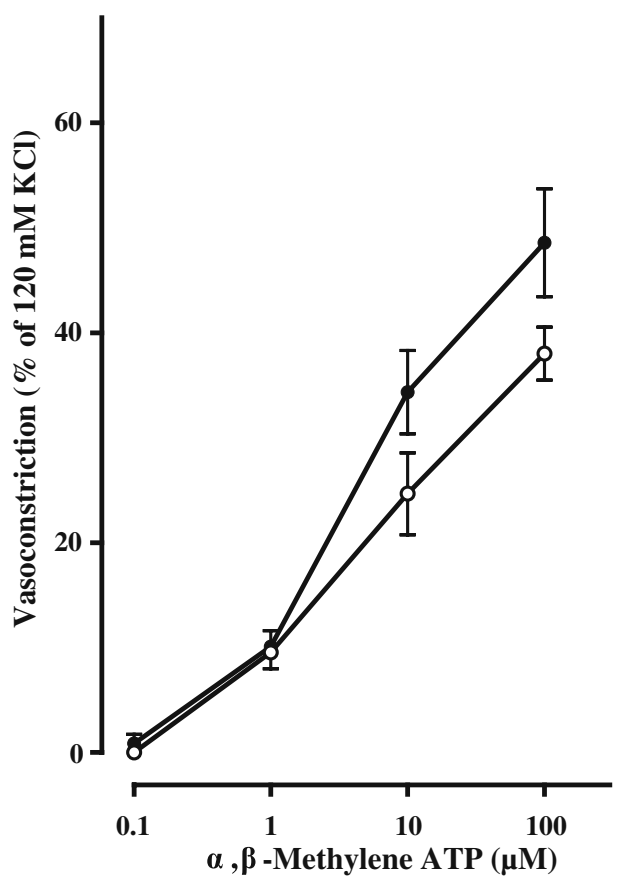




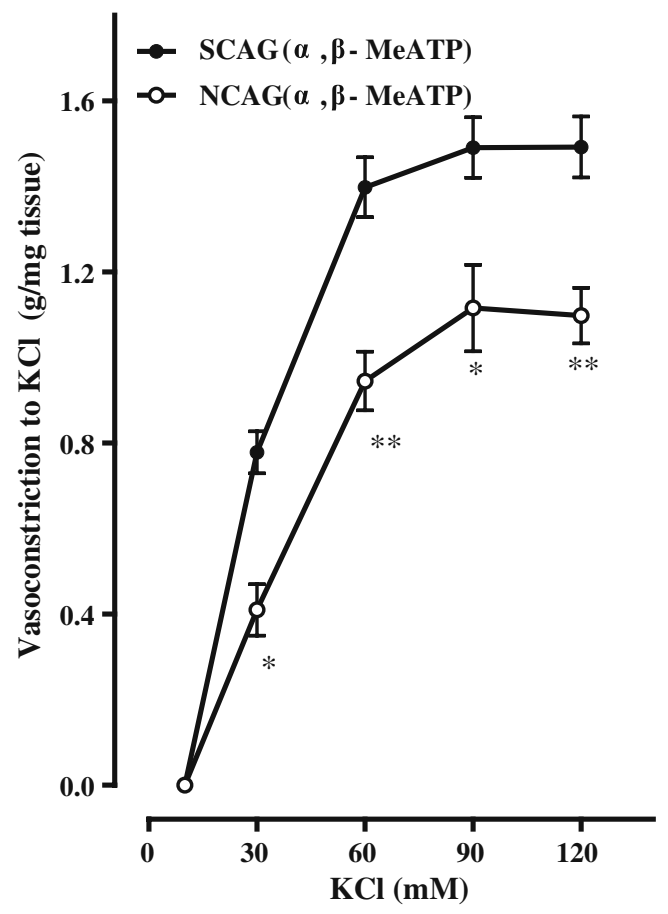

Fig. 3 Vasoconstrictive responses to $\mathrm{KCl}$ in the mesenteric arteries used in single concentration administration $[\alpha, \beta$-methylene ATP $(\alpha, \beta$-MeATP $)$ ] group [SCAG $(\alpha, \beta$-MeATP $), n=20]$ and in noncumulative administration $(\alpha, \beta$-MeATP) group [NCAG $(\alpha, \beta$-MeATP $), n=$ 5]. Points represent the mean values, and vertical bars show S.E. mean. ${ }^{*} P<0.05$ and ${ }^{* *} P<0.01$ vs. SCAG $(\alpha, \beta-$ MeATP $)$

vasoconstrictive responses in a concentration-dependent manner in these different types of arteries. When the vasoconstrictive responses to NA were normalized to the tissue wet weight $(\mathrm{g} / \mathrm{mg}$ tissue), the rank order of the maximal vasoconstrictive responses $\left(E_{\max }\right)$ was caudal $>$ mesenteric $>$ internal carotid $>$ pulmonary $=$ aorta (Fig. 4a). In addition, when the vasoconstrictive responses to NA were normalized to the maximal vasoconstriction induced by $\mathrm{KCl}\left(\% \mathrm{KCl} E_{\max }\right)$, the rank order of the $E_{\max }$ was internal carotid $>$ aorta $>$ pulmonary $=$ mesenteric $>$ caudal (Fig. 5a). The range of $-\log \mathrm{EC}_{50}(\mathrm{~mol} / \mathrm{l})$ values for $\mathrm{NA}$ in the five types of arteries was 6.9-7.8, and the rank order was caudal $=$ mesenteric $<$ internal carotid $<$ aorta $=$ pulmonary (Table 1).
Vasoconstrictive responses to a single concentration of $\alpha, \beta$-MeATP in the thoracic aorta and pulmonary, internal carotid, mesenteric, and caudal arteries

$\alpha, \beta$-MeATP produced a concentration-dependent vasoconstrictive responses in the thoracic aorta and pulmonary, internal carotid, mesenteric, and caudal arteries (each arterial preparation was only exposed to $\alpha, \beta$-MeATP once). There were no significant differences for the wet weight of preparations used between NA and $\alpha, \beta$-MeATP experiments $(P>0.05$, Fig. 6a). The maximal vasoconstrictive response to $\mathrm{KCl}$ in each type of the preparations used in the NA experiments was not significantly different from that used in the $\alpha, \beta$-MeATP experiments $(P>0.05$, Fig. $6 \mathrm{~b})$. The rank order of the $E_{\max }$ was caudal $>$ mesenteric $>$ internal carotid $>$ pulmonary $=$ aorta when the vasoconstrictive responses to $\alpha, \beta$-MeATP were normalized to tissue wet weight ( $\mathrm{g} / \mathrm{mg}$ tissue; Fig. $4 \mathrm{~b}$ ), whereas it was internal carotid $=$ caudal $>$ aorta $>$ pulmonary $=$ mesenteric when normalized to maximal vasoconstriction induced by $\mathrm{KCl}\left(\% \mathrm{KCl} E_{\max } ; \mathrm{Fig} .5 \mathrm{~b}\right)$. The range of $-\log \mathrm{EC}_{50}(\mathrm{~mol} / \mathrm{l})$ values for $\alpha, \beta$-MeATP in the five types of arteries was 4.95.9 , and their rank order was pulmonary $=$ aorta $=$ internal carotid $<$ mesenteric $=$ caudal $($ Table 1$)$. The values of $\left(E_{\max \cdot \alpha, \beta \text {-MeATP }} / E_{\max \cdot \mathrm{KCl}}\right) /\left(E_{\max \cdot \mathrm{NA}} / E_{\max \cdot \mathrm{KCl}}\right)$ were $0.8,0.4$, $0.4,0.4$, and 0.4 for the caudal, internal carotid, mesenteric, pulmonary arteries, and aorta, respectively. The range of $\mathrm{EC}_{50}(\mathrm{mmol} / \mathrm{l})$ values for $\mathrm{KCl}$ in the five types of arteries used in NA group was 16.8-29.9, and their rank order was caudal $>$ mesenteric $=$ internal carotid $>$ aorta $=$ pulmonary (Table 1). The $\mathrm{EC}_{50}$ values of $\mathrm{KCl}$ in the five types of arteries used in NA group were significantly smaller than those in $\alpha, \beta$-MeATP group (Table1).

\section{Discussion}

Isometric vasoconstrictive responses to $\alpha, \beta$-MeATP were often expressed as a percentage of the contractile response to high $\mathrm{KCl}$ solution in order to investigate pharmacological characterization in different types of arteries [13, 29]. However, our present study found that the vasoconstrictive
Table 1 The $-\log \mathrm{EC}_{50}(\mathrm{~mol} / \mathrm{l})$ for NA and $\alpha, \beta$-MeATP as well as $\mathrm{EC}_{50}(\mathrm{mmol} / \mathrm{l})$ for $\mathrm{KCl}$ in various isolated arterial preparations

\footnotetext{
$* P<0.05, * * P<0.01$ vs. C;

${ }^{\triangle} P<0.05,{ }^{\triangle \triangle} P<0.01$ vs. M;

${ }^{\#} P<0.05$ vs. $P$; ${ }^{@} P<0.05$,

@@ $P<0.01$ vs. NA group
}

\begin{tabular}{|c|c|c|c|c|}
\hline \multirow[t]{2}{*}{ Artery } & \multicolumn{2}{|c|}{ NA group $(n=8)$} & \multicolumn{2}{|c|}{$\alpha, \beta-$ MeATP group $(n=20)$} \\
\hline & NA & $\mathrm{KCl}$ & $\alpha, \beta-\mathrm{MeATP}$ & $\mathrm{KCl}$ \\
\hline Caudal (C) & $6.9 \pm 0.1$ & $29.9 \pm 1.4$ & $5.9 \pm 0.2$ & 41.8土0.4@@ \\
\hline Mesenteric (M) & $7.0 \pm 0.1$ & $24.1 \pm 0.4^{* *}$ & $5.5 \pm 0.2$ & 30.1土0.8@@ \\
\hline Internal carotid (I) & $7.4 \pm 0.1^{* * \#}$ & $22.7 \pm 1.2^{* * \#}$ & $5.1 \pm 0.2^{* *}$ & $28.4 \pm 1.3^{@}$ \\
\hline Aorta (A) & $7.6 \pm 0.1^{* * \Delta \Delta}$ & $19.3 \pm 0.6^{* * \Delta}$ & $4.9 \pm 0.1^{* * \Delta}$ & 22.7士0.4@@ \\
\hline Pulmonary (P) & $7.8 \pm 0.1^{* * \Delta \Delta}$ & $16.8 \pm 1.0^{* * \Delta \Delta}$ & $5.1 \pm 0.1^{* * \Delta}$ & 23.2士0.3@@ \\
\hline
\end{tabular}


Fig. 4 Vasoconstrictive responses to noradrenaline (a $n=8$ ) and $\alpha, \beta$-methylene ATP (b $n=20$, each preparation exposed to $\alpha, \beta$-methylene ATP once) expressed as $\mathrm{g} / \mathrm{mg}$ tissue in the caudal, mesenteric, internal carotid, pulmonary and aortic arteries. Points represent the mean values, and vertical bars show S.E. mean

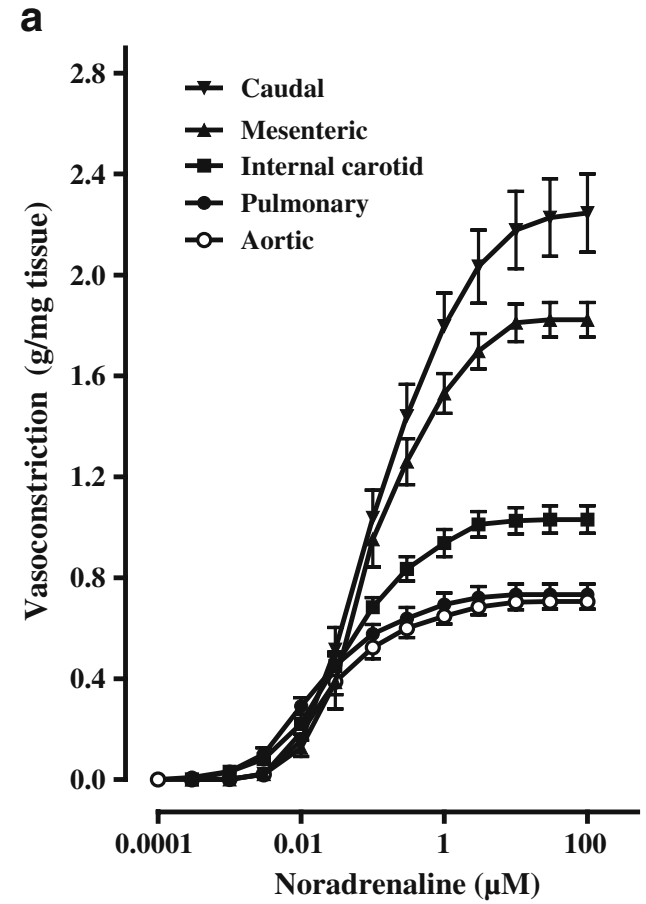

b

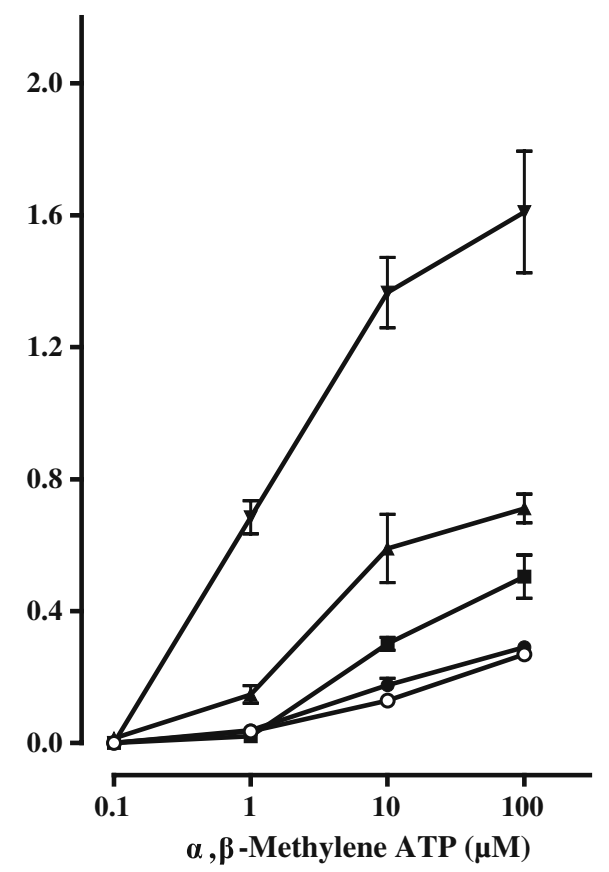

responses to $\mathrm{KCl}$ in the rat isolated mesenteric arteries in noncumulative administration $(\alpha, \beta$-MeATP) group were significantly smaller than that in single concentration administration $(\alpha, \beta-$-MeATP) group or in NA control group. Although the maximal vasoconstrictions induced by $\mathrm{KCl}$ in tail, internal carotid, mesenteric, pulmonary arteries, and aorta used in single concentration administration $(\alpha, \beta-$ MeATP) group were not different from that used in NA control group, $\mathrm{EC}_{50}$ values of $\mathrm{KCl}$ became significantly greater in these five types of arteries in single concentration administration $(\alpha, \beta$-MeATP) group compared to NA control group. Additionally, the vasoconstrictive responses to $\alpha, \beta$-MeATP expressed as $\mathrm{g} / \mathrm{mg}$ tissue in single concentration administration group were significantly greater than that in noncumulative administration group in the ratisolated mesenteric arteries. Since the vasoconstrictive responsiveness tested by NA at the beginning of the study in the group of single concentration of $\alpha, \beta$-MeATP was not
Fig. 5 Vasoconstrictive responses to noradrenaline (a $n=8)$ and $\alpha, \beta$-methylene ATP (b $n=20$, each preparation exposed to $\alpha, \beta$-methylene ATP once) expressed as percentage of the maximal vasoconstriction to $120 \mathrm{mmol} / 1 \mathrm{KCl}$ in the internal carotid, aortic, pulmonary, mesenteric and caudal arteries. Points represent the mean values, and vertical bars show S.E. mean a

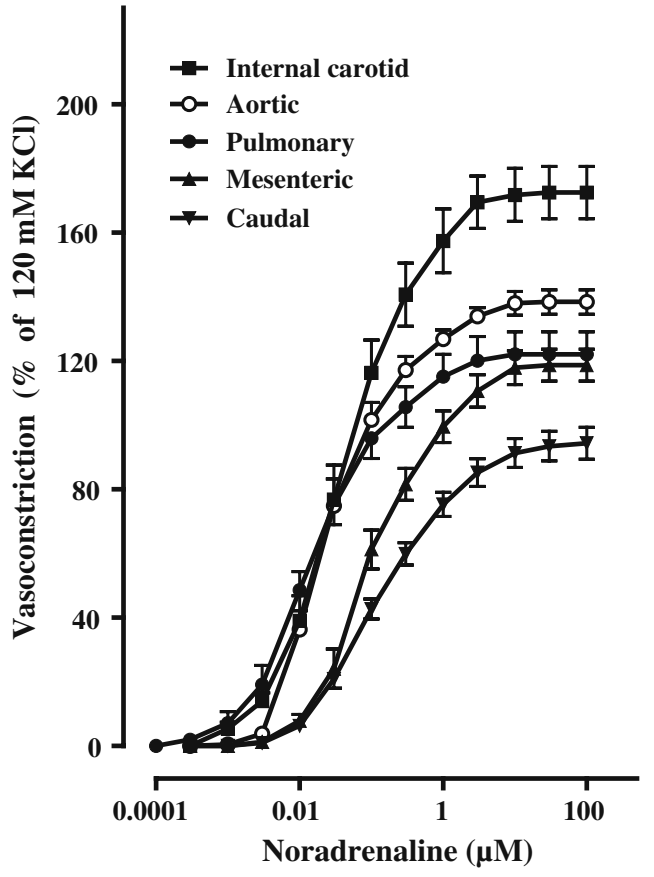

b

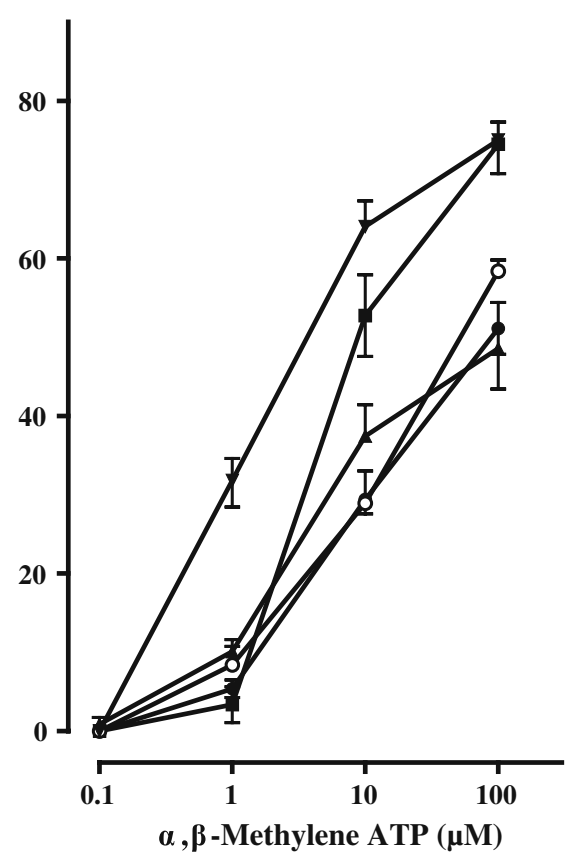


Fig. 6 Tissue wet weight (a) and maximal vasoconstriction to $120 \mathrm{mmol} / 1 \mathrm{KCl}(\mathbf{b})$ of the internal carotid (Int), pulmonary $(P u l)$, aortic (Aor), mesenteric (Mes) and caudal ( $\mathrm{Cau})$ arteries treated with single concentration of $\alpha, \beta$-methylene ATP $(\alpha, \beta-M e A T P, n=20)$ or with noradrenaline $(N A, n=8)$. Columns represent the mean values, and vertical bars show S.E. mean
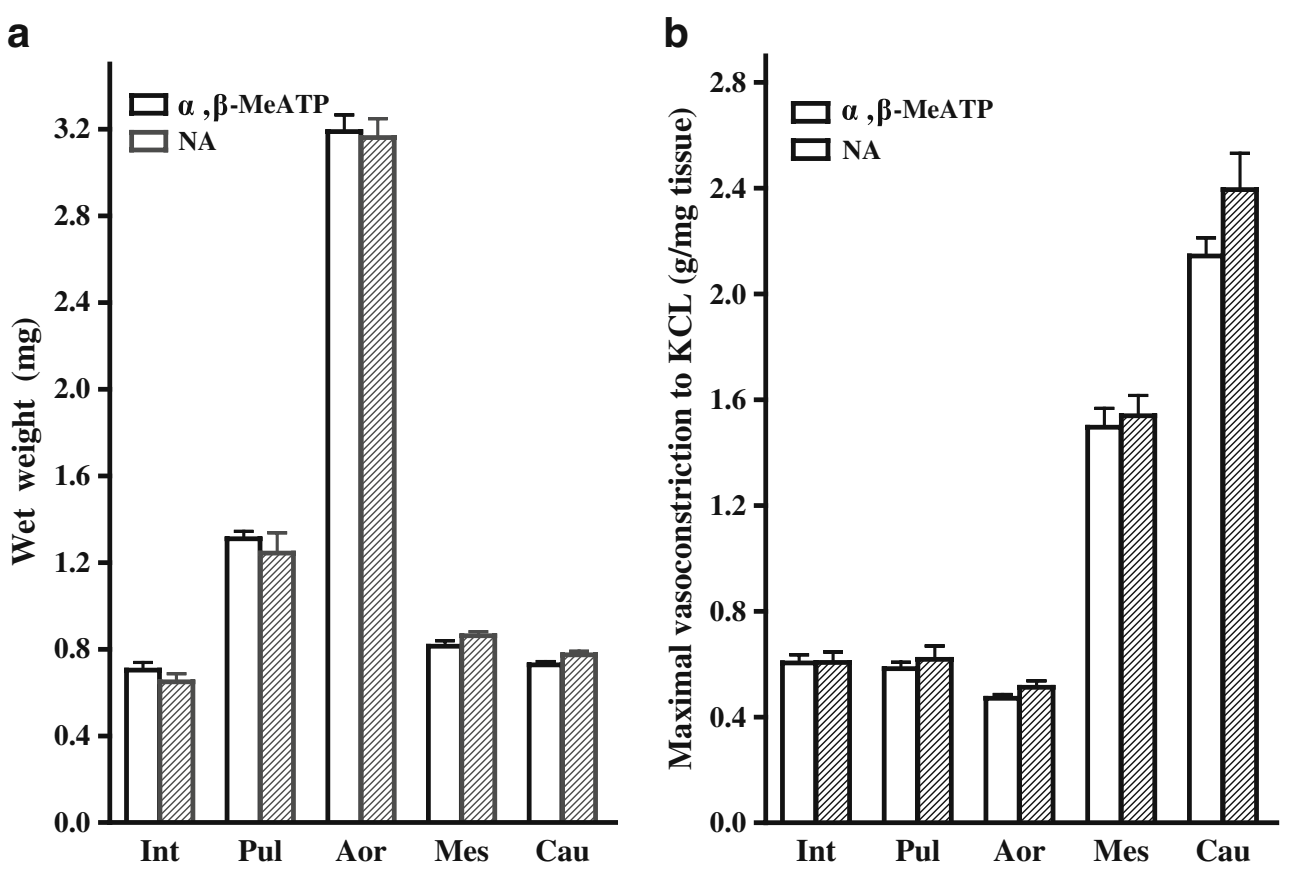

significantly different from that in the group of noncumulative administration of $\alpha, \beta$-MeATP, and there was no significant difference in the wet weight of the mesenteric arterial preparations between these two groups, we suggest that repeated exposure of the rat isolated mesenteric artery to higher concentration of $\alpha, \beta$-MeATP obviously suppresses not only $\mathrm{P} 2 \mathrm{X}_{1}$ receptor-mediated vasoconstriction but also $\mathrm{KCl}$-induced vasoconstriction. Noncumulative administration regime is not suitable for $\alpha, \beta$-MeATPinduced vasoconstriction, at least in the study of the ratisolated mesenteric artery. It is should be noted that the vasoconstrictive response to $\alpha, \beta$-MeATP administered in noncumulative manner was artificially more enlarged when the responses were normalized to the maximal contraction induced by $120 \mathrm{mmol} / \mathrm{K} \mathrm{KCl}$ compared to the responses expressed as g/mg tissue (Fig. 2). Our experimental results clearly showed that $\mathrm{P} 2 \mathrm{X}_{1}$ receptor-mediated vasoconstrictive responses largely desensitized during noncumulative administration of $\alpha, \beta$-MeATP to the rat mesenteric artery. This administration regime also affected $\mathrm{KCl}$-related vasoconstrictive responses.

In this study, we employed a single concentration administration of $\alpha, \beta$-MeATP to avoid the profound desensitization of $\mathrm{P} 2 \mathrm{X}_{1}$ receptors and firstly reported the regional characteristic of $\mathrm{P}_{2} \mathrm{X}_{1}$ receptor-regulated vasoconstriction in the rat isolated thoracic aorta and pulmonary, internal carotid, mesenteric, and caudal arteries, in comparison with $\alpha_{1}$-adrenoceptor-regulated vasoconstriction. We showed that wet weight of each type preparation of the five regional arteries used in the NA group was not significantly different from that used in the $\alpha, \beta$-MeATP group, and there was no significant difference in the vasoconstrictive responsiveness tested by NA at the beginning of the study in each type of the arteries between the two groups. Moreover, the maximal vasoconstrictive response to $\mathrm{KCl}$ of each type preparation of the five regional arteries used in the NA group was not significantly different from that used in the $\alpha, \beta$-MeATP group, although the $\mathrm{EC}_{50}$ values of $\mathrm{KCl}$ became significantly greater in the $\alpha, \beta$-MeATP group. The vasoconstrictive response to $\mathrm{KCl}(120 \mathrm{mmol} / \mathrm{l})$ is usually used to assess the contractile ability of the vascular smooth muscle. Agonist-induced vasoconstrictions are often standardized by $E_{\max \cdot \mathrm{KCl}}$ in order to eliminate an influence of the different thickness of muscle layer in larger and smaller arteries [30-32]. Therefore, it was reasonable to compare the magnitude of the vasoconstriction induced by $\alpha, \beta$ MeATP with that induced by NA, regardless of the responses expressed as $\mathrm{g} / \mathrm{mg}$ tissue or as a percentage of the maximal vasoconstriction to $\mathrm{KCl}$ in this study.

When the vasoconstrictive responses to $\alpha, \beta$-MeATP and NA in the five regional arteries were expressed as $\mathrm{g} / \mathrm{mg}$ tissue, both the rank orders of the $E_{\max \cdot \alpha, \beta \text {-MeATP and }}$ $E_{\text {max }}$ NA were the same, i.e., caudal $>$ mesenteric $>$ internal carotid $>$ pulmonary $=$ aorta. In addition, when we normalized the vasoconstrictive response to a maximal contraction of $\mathrm{KCl}$, the rank order of $E_{\max \cdot \alpha, \beta-\text { MeATP was }}$ caudal $=$ internal carotid $>$ aorta $>$ pulmonary $=$ mesenteric, and the rank order of $E_{\max \cdot N A}$ was internal carotid $>$ aorta $>$ pulmonary $=$ mesenteric $>$ caudal. Obviously, the rank order of $E_{\max \text { NA }}$ was the same as that of $E_{\max \cdot \alpha, \beta \text {-MeATP in }}$ four different arteries of the internal carotid, pulmonary, mesenteric arteries, and aorta, regardless of the vasoconstrictions expressed as $\mathrm{g} / \mathrm{mg}$ tissue or as a percentage of the maximal vasoconstriction to $\mathrm{KCl}$. Moreover, the 
values of $\left(E_{\max \cdot \alpha, \beta-\mathrm{MeATP}} / E_{\max \cdot \mathrm{KCl}}\right) /\left(E_{\max \cdot \mathrm{NA}} / E_{\max \cdot \mathrm{KCl}}\right)$ in the internal carotid, mesenteric, pulmonary arteries, and aorta were about 0.4 , indicating that $\alpha, \beta$-MeATP-mediated vasoconstriction reaches at least $40 \%$ of the maximal vasoconstriction to NA in these arteries.

On the other hand, it is widely accepted that $\mathrm{P} 2 \mathrm{X}_{1}$ receptor seems to be the most important P2X subtype in vascular smooth muscle [8], although this concept is not a result from functional study. Nori et al. [33] observed the coexpression of mRNAs of three P2X receptor subtypes $\left(\mathrm{P} 2 \mathrm{X}_{1}, \mathrm{P} 2 \mathrm{X}_{2}\right.$, and $\left.\mathrm{P} 2 \mathrm{X}_{4}\right)$ in rat vascular smooth muscle. Some previous studies found that $\mathrm{P}_{2} \mathrm{X}_{4}$ subtype did not couple to a vasomotor response [34] and that $\mathrm{P} 2 \mathrm{X}_{2}$ receptor was mainly located on nerves and arterial endothelial cells, but with low density on the smooth muscle cells [35]. $\alpha, \beta-$ MeATP was inactive as an agonist at the recombinant $\mathrm{P} 2 \mathrm{X}_{2}$ receptor [36]. Recently, Wallace et al. [37] investigated the expression of P2X receptor subtypes by immunohistochemistry in the tail and mesenteric arteries of rats aged 4, 6, and 12 weeks. $\mathrm{P} 2 \mathrm{X}_{1}$ receptor-specific immunoreactivity was associated with the smooth muscle layer of both arteries from rats aged 4, 6, and 12 weeks, and $\mathrm{P} 2 \mathrm{X}_{4}$ receptor subtype was weakly expressed in the smooth muscle layer of 4-week and 6-week tail artery and 4-week and 12-week mesenteric artery, but other subtypes of P2X receptors were not detected in the smooth muscle layer of 6-week and 12week arteries [37]. In our study, 12- to 13-week-old rats $(300-350 \mathrm{~g})$ were used, and the vascular endothelium of the regional arteries was removed. Therefore, it is likely that $\mathrm{P} 2 \mathrm{X}_{1}$ receptors are mainly involved in the vasoconstrictive responses to $\alpha, \beta$-MeATP in the present study.

Since there was a very high level of consistency between the vasoconstrictions induced by $\alpha, \beta$-MeATP and NA in the rat-isolated internal carotid, mesenteric, pulmonary arteries, and aorta, we suggest that the activation of $\mathrm{P} 2 \mathrm{X}_{1}$ receptor plays an important role in physiological regulation of the vascular tone of these arteries, and the maximal vasoconstrictions mediated via $\mathrm{P} 2 \mathrm{X}_{1}$ receptors reach at least $40 \%$ of those mediated via $\alpha_{1}$-adrenoceptors in the internal carotid, mesenteric, pulmonary arteries, and aorta of the rat. Furthermore, the value of $\left(E_{\max \cdot \alpha, \beta-\mathrm{MeATP}} / E_{\max \cdot \mathrm{KCl}}\right) /$ $\left(E_{\max \cdot \mathrm{NA}} / E_{\max \cdot \mathrm{KCl}}\right)$ in the tail artery was 0.8 , which was much bigger than the values of other four arteries, indicating much more functional $\mathrm{P} 2 \mathrm{X}_{1}$ receptors distributed in the rat tail artery. Tail heat loss and blood flow increase with ambient temperature [38] as well as with increasing body temperature in the rat [39]. Directing blood into the tail causes heat loss, while conversely restricting blood flow to the tail reduces heat loss in the cold. The presence of a greater purinergic vasoconstriction in the rat tail artery than other regional arteries might suggest that extracellular nucleotides play an important role in the normal physiological functions such as thermoregulation and balance. In contrast to other regions of arteries, $\mathrm{P} 2 \mathrm{X}_{1}$ receptor-mediated vasoconstriction in rat tail artery is unique not only in its potent vasoconstrictive feature but also in its higher affinity to $\alpha, \beta$-MeATP.

In the isolated vascular experiments, vasoconstrictive responses were often normalized to the vasoconstriction induced by $\mathrm{KCl}$ which was applied at the beginning of experiments in previous studies [13, 29, 40, 41]. The main issue in present study is whether $\mathrm{KCl}$ administration at the beginning of experimentation affects vasoconstrictive responses to $\alpha, \beta$-MeATP. However, our present study did not show any evidence about the influence of an initial administration of $\mathrm{KCl}$ on responses to $\alpha, \beta$-MeATP, even though we found that initial administration of $\alpha, \beta$-MeATP significantly changed the $\mathrm{EC}_{50}$ values of $\mathrm{KCl}$ in the tail, internal carotid, mesenteric, pulmonary arteries, and aorta of the rat.

In conclusion, $\mathrm{P} 2 \mathrm{X}_{1}$ receptor-mediated vasoconstrictions are equally important in the rat internal carotid, pulmonary, mesenteric arteries, and aorta, but they are much greater in the rat tail artery, suggesting a special role in its physiological function.

Acknowledgements This work was supported by a grant from the National Program on Key Basic Research Project of China (973 Program; No. 2005CB523301).

\section{Conflicts of interest None}

\section{References}

1. Kennedy C, Saville VL, Burnstock G (1986) The contributions of noradrenaline and ATP to the response of the rabbit central ear artery to sympathetic nerve stimulation depend on the parameters of stimulation. Eur J Pharmacol 122:291-300

2. Burnstock G, Warland JJ (1987) A pharmacological study of the rabbit saphenous artery in vitro: a vessel with a large purinergic contractile response to sympathetic nerve stimulation. $\mathrm{Br} \mathrm{J}$ Pharmacol 90:111-120

3. Brizzolara AL, Burnstock G (1990) Evidence for noradrenergicpurinergic cotransmission in the hepatic artery of the rabbit. Br J Pharmacol 99:835-839

4. Ren LM, Burnstock G (1997) Prominent sympathetic purinergic vasoconstriction in the rabbit splenic artery: potentiation by $2,2^{\prime}-$ pyridylisatogen tosylate. Br J Pharmacol 120:530-536

5. Bo X, Burnstock G (1993) Heterogeneous distribution of $\left[{ }^{3} \mathrm{H}\right] \alpha$, $\beta$-methylene ATP binding sites in blood vessels. J Vasc Res 30:87-101

6. Ramme D, Regenold JT, Starke K, Busse R, Illes P (1987) Identification of the neuroeffector transmitter in jejunal branches of rabbit mesenteric artery. Naunyn-Schmiedeberg's Arch Pharmacol 336:267-273

7. Boarder MR, Hourani SM (1998) The regulation of vascular function by $\mathrm{P} 2$ receptors: multiple sites and multiple receptors. Trends Pharmacol Sci 19:99-107

8. Valera S, Hussy N, Evans RJ, Adami N, North RA, Surprenant A, Buell G (1994) A new class of ligand-gated ion channel defined by P2X receptor for extracellular ATP. Nature 371:516-519 
9. Collo G, North RA, Kawashima E, Merlo-Pich E, Neidhart S, Surprenant A, Buell G (1996) Cloning of $\mathrm{P}_{2} \mathrm{X}_{5}$ and $\mathrm{P} 2 \mathrm{X}_{6}$ receptors and the distribution and properties of an extended family of ATP-gated ion channels. J Neurosci 16:2495-2507

10. Galligan JJ, Hess MC, Miller SB, Fink GD (2001) Differential localization of $\mathrm{P} 2$ receptor subtypes in mesenteric arteries and veins of normotensive and hypertensive rats. J Pharmacol Exp Ther 296:478-485

11. Vial C, Evans RJ (2002) $\mathrm{P} 2 \mathrm{X}_{1}$ receptor-deficient mice establish the native $\mathrm{P} 2 \mathrm{X}$ receptor and a $\mathrm{P}_{2} \mathrm{Y}_{6}$-like receptor in arteries. Mol Pharmacol 62:1438-1445

12. Erlinge D, Burnstock G (2008) P2 receptors in cardiovascular regulation and disease. Purinergic Signal 4:1-20

13. Steinmetz M, Bierer S, Hollah P, Rahn KH, Schlatter E (2000) Heterogenous vascular effects of AP5A in different rat resistance arteries are due to heterogenous distribution of $\mathrm{P} 2 \mathrm{X}$ and $\mathrm{P} 2 \mathrm{Y}_{1}$ purinoceptors. J Pharmacol Exp Ther 294:1182-1187

14. Malmsjö M, Bergdahl A, Möller S, Zhao XH, Sun XY, Hedner T, Edvinsson L, Erlinge D (1999) Congestive heart failure induces downregulation of $\mathrm{P} 2 \mathrm{X}_{1}$-receptors in resistance arteries. Cardiovasc Res 43:219-227

15. Wihlborg AK, Slätt J, Sun X, Zhao XH, Malmsjö M, Bergman J, Hedner T, Erlinge D (2003) 2,2'-Nitrophenylisatogen potentiates $\mathrm{P} 2 \mathrm{X}_{1}$ receptor mediated vascular contraction and blood pressure elevation. Drug Dev Res 59:82-87

16. Liu SF, McCormack DG, Evans TW, Barnes PJ (1989) Characterization and distribution of P2-purinoceptor subtypes in rat pulmonary vessels. J Pharmacol Exp Ther 251:1204-1210

17. Mombouli JV, Vanhoutte PM (1993) Purinergic endotheliumdependent and -independent contractions in rat aorta. Hypertension 22:577-583

18. O'Connor SE, Wood BE, Leff P (1990) Characterization of $\mathrm{P}_{2 x}$ receptors in rabbit isolated ear artery. Br J Pharmacol 101:640-644

19. Zhao D, Ren LM (2005) Non-adrenergic inhibition at prejunctional sites by agmatine of purinergic vasoconstriction in rabbit saphenous artery. Neuropharmacology 48:597-606

20. Zhao D, Ren LM, Lu HG, Zhang X (2008) Potentiation by yohimbine of $\alpha$-adrenoceptor-mediated vasoconstriction in response to clonidine in the rabbit ear vein. Eur $\mathrm{J}$ Pharmacol 589:201-205

21. Park JY, Shin HK, Lee YJ, Choi YW, Bae SS, Kim CD (2009) The mechanism of vasorelaxation induced by Schisandra chinensis extract in rat thoracic aorta. J Ethnopharmacol 121:69-73

22. Oriowo MA, Chandrasekhar B, Kadavil EA (2003) $\alpha_{1}$-Adrenoceptor subtypes mediating noradrenaline-induced contraction of pulmonary artery from pulmonary hypertensive rats. Eur J Pharmacol 482:255263

23. Massett MP, Lewis SJ, Bates JN, Kregel KC (1998) Effect of heating on vascular reactivity in rat mesenteric arteries. J Appl Physiol 85:701-708

24. Jähnichen S, Eltze M, Pertz HH (2004) Evidence that $\alpha_{1 B^{-}}$ adrenoceptors are involved in noradrenaline-induced contractions of rat tail artery. Eur J Pharmacol 488:157-167
25. Leff P, Wood BE, O'Connor SE (1990) Suramin is a slowlyequilibrating but competitive antagonist at $\mathrm{P} 2 \mathrm{X}$-receptors in the rabbit isolated ear artery. Br J Pharmacol 101:645-649

26. Burnstock G, Kennedy C (1985) Is there a basis for distinguishing two types of P2-purinoceptor? Gen Pharmacol 16:433-440

27. Ren LM, Zhang M (2002) Distribution of functional $P 2 X_{1}$-like receptor in isolated rabbit arteries. Acta Pharmacol Sin 23:721726

28. Muramatsu I, Ohmura T, Kigoshi S, Hashimoto S, Oshita M (1990) Pharmacological subclassification of $\alpha$-adrenoceptors in vascular smooth muscle. Br J Pharmacol 99:197-201

29. Chootip K, Ness KF, Wang Y, Gurney AM, Kennedy C (2002) Regional variation in $\mathrm{P} 2$ receptor expression in the rat pulmonary arterial circulation. Br J Pharmacol 137:637-646

30. Vails AJ, Crowe R, Burnstock G (1997) A neuromodulatory role for neuronal nitric oxide in the rabbit renal artery. Br J Pharmacol 121:213-220

31. Bo X, Sexton A, Xiang Z, Nori SL, Burnstock G (1998) Pharmacological and histochemical evidence for P2X receptors in human umbilical vessels. Eur J Pharmacol 353:59-65

32. Garcia-Villalon AL, Garcia JL, Fernandez N, Monge L, Gomez B, Dieguez G (1996) Regional differences in the arterial response to vasopressin: role of endothelial nitric oxide. $\mathrm{Br} \mathrm{J}$ Pharmacol 118:1848-1854

33. Nori S, Fumagalli L, Bo X, Bogdanov Y, Burnstock G (1998) Coexpression of mRNAs for P2X1, P2X2 and P2X4 receptors in rat vascular smooth muscle: an in situ hybridization and RT-PCR study. J Vasc Res 35:179-185

34. Ralevic V, Burnstock G (1998) Receptors for purines and pyrimidines. Pharmacol Rev 50:413-492

35. Hansen MA, Dutton JL, Balcar VJ, Barden JA, Bennett MR (1999) P2X (purinergic) receptor distributions in rat blood vessels. J Auton Nerv Syst 75:147-155

36. Brake AJ, Wagenbach MJ, Julius D (1994) New structural motif for ligand-gated ion channels defined by an ionotropic ATP receptor. Nature 371:519-523

37. Wallace A, Knight GE, Cowen T, Burnstock G (2006) Changes in purinergic signalling in developing and ageing rat tail artery: importance for temperature control. Neuropharmacology 50:191208

38. Rand RP, Burton AC, Ing T (1965) The tail of the rat, in temperature regulation and acclimatization. Can J Physiol Pharmacol 43:257-267

39. Raman ER, Vanhuyse VJ, Roberts MF (1987) Mathematical circulation model for the blood-flow-heat-loss relationship in the rat tail. Phys Med Biol 32:859-875

40. Ajay M, Achike FI, Mustafa MR (2007) Modulation of vascular reactivity in normal, hypertensive and diabetic rat aortae by a nonantioxidant flavonoid. Pharmacol Res 55:385-391

41. Yu J, Tokinaga Y, Kuriyama T, Uematsu N, Mizumoto K, Hatano $\mathrm{Y}$ (2005) Involvement of $\mathrm{Ca}^{2+}$ sensitization in ropivacaineinduced contraction of rat aortic smooth muscle. Anesthesiology 103:548-555 